\title{
What drives millennials and zillennials continuously using instant messaging? Perspective from Indonesia
}

\section{Putu Laksmita Dewi Rahmayantia ${ }^{a}$, Ida Bagus Agung Dharmanegara ${ }^{b}$, Ni Nyoman Kerti Yasa ${ }^{c^{*}}$, I Putu Gde Sukaatmadja ${ }^{c}$, Komang Agus Satria Pramudana ${ }^{c}$, Gede Bayu Rahanata ${ }^{c}$, G Gusti Ayu Ketut Giantaric and Martaleni ${ }^{\mathrm{d}}$}

\author{
${ }^{a}$ Faculty of Economics, Business and Tourism, Hindu Indonesia University, Bali, Indonesia \\ ${ }^{b}$ Warmadewa University, Bali, Indonesia \\ ${ }^{c}$ Faculty of Economics and Business, Udayana University, Bali, Indonesia \\ ${ }^{d}$ Faculty of Economics and Business, Gajayana University, Malang, Indonesia

\section{H R O N I C L E \\ A B S T R A C T}

Article history:

Received: June 29, 2021

Received in revised format: Sep-

tember 29, 2021

Accepted: November 8, 2021

Available online: November 8 ,

2021

Keywords:

Marketing

Instant Messaging

Millennials Generation

Continuous Usage intention

\begin{abstract}
This study proposes to explore the relationship between perceived risk, subjective norm, perceived value, and continuous usage intention via trust as a mediating variable. This research applied a survey which involved 320 IM users (160 from millennials and 160 from Zillennial) in Indonesia. The literature's existing scales were used to operationalize the constructs proposed in this study. The analyses were conducted using partial least squares structural equation modeling (PLS-SEM) to test hypotheses. The results of the study show that there are differences in the results of the influence of perceived risk on continuous usage intention in the Millennial and Zillennial generations. The results of the study found that continuous usage intention received negative direct impact from perceived risk, positive direct effect from subjective norm, perceived value, and trust on Millennial. In addition, continuous usage intention received negative and not significant direct impact from perceived risk, positive direct effect from subjective norm, perceived value, and trust on Zillennial. The results are useful for instant messaging management into formulating strategies to retain their users in Indonesia. These findings provided theoretical and managerial contributions as well as future research directions.
\end{abstract}

\section{Introduction}

A person can change their daily lifestyle drastically with the development of today's digital world. The use of smartphones is increasing, instant messaging (IM) applications have become a necessity for users. Free IM applications are widely available today due to technological developments which have shown tremendous improvement in them. Instant messaging services allow people to communicate with friends via text, phone calls, videos, shared files, whether to join a group or not, to save contacts and this communication can take place globally. Several types of IM that are popular today in Indonesia are WhatsApp, Line, WeChat, Facebook Messenger, and Telegram. WhatsApp is still the market leader in this sector. The number of monthly active users of WhatsApp is 2000 million users, while other IMs are lower than that number (Statistica, 2021). However, according to news quoted in Business Insider (2019), it was stated that an IM application was hacked, and hackers

* Corresponding author.

E-mail address: kertiyasa@unud.ac.id (N.N.K. Yasa)

(C) 2022 by the authors; licensee Growing Science, Canada. doi: $10.5267 /$ j.ijdns.2021.11.001 
installed spyware on a number of users' smartphones. By making phone calls to their targets, these hackers install surveillance devices, posing a threat to IM's ability to retain users. If consumers continue to use the app, it will benefit the service provider's business and allow it to continue operating. The ambition to utilize a product indefinitely is referred to as continuous consumption intention (Wang, 2016a). Encouragement of ongoing usage intention by consumers is a crucial strategy for market development and maintenance, according to marketing management (Deng et al., 2017). Various theories have been used to study continuous usage. Researchers argue that many of these theories are not always suitable for studying sustainable use behavior. After an in-depth literature review, Nabavi et al. (2016) concluded that the theory still needs to be developed to predict continuous usage intention. More study is needed to construct a more appropriate model to comprehend the behavior of continuous usage intention rather than relying on the existing model.

Subjective norm is one of the drivers of behavioral intentions in the Theory of Planned Behavior (TPB), which has become one of the most important theories in understanding and predicting behavior (Salleh \& Laxman, 2015). It can be used to explain individual intentions to use various forms of information technology as well as technological acceptance (Kurdi et al., 2021). A person's subjective conviction that most other people think he or she should (or should not) behave in a certain way is known as a subjective norm (Ho et al., 2017). The demand for approval from significant persons will motivate those who hold subjective norms (Liu et al., 2019). Users of instant messaging (IM) are linked to others. In other words, one or more important references, particularly from major reference groups such as friends and family, have a strong influence on IM users (Hossain, 2019). Subjective norm has been found to have a positive and significant effect on continuous usage intention (Hossain et al., 2019; Mouakket, 2018; Mkhize, 2021; and Aji et al., 2020); however, due to voluntary participation and relatively low switching costs in online communities, subjective norm has a smaller impact on determining user intentions (Liu et al., 2019; Rahmayanti \& Rahyuda, 2020). Other variables, such as perceived risk, influence continuous usage intention in addition to subjective norms. Negative consequences that are discordant with expectations that can occur while utilizing an instant messenger are referred to as perceived risk. Users tend to stop using IM services if they think there are security issues, such as hacks and data leaks. Threats to information security are the main barriers that make users hesitant to use IM services (Park et al., 2019). Previous research has found that perceived risk has a negative and significant effect on continuous usage intention (Park et al., 2019; Khan et al., 2020; Obaid, 2021), but Nuryasman and Warningsih (2016) found that perceived risk has no significant effect on continuous usage intention, indicating that additional variables are required to fill this research gap. Continuous usage intention can also be influenced by perceived value. Perceived value can also be the basis for understanding consumer behavior (Shaikh \& Karjaluoto, 2016). Perceived value is a consumer's overall assessment of a product's usefulness based on their perception of what they get in exchange for what they contribute (Zeithaml, 1988, p.4) Any business's top priority is to provide value to customers while also extracting value for the organization (Kumar \& Reinartz, 2016). Perceived value is the foundation for many organizational operations, and it is regarded crucial to a company's success due to its impact on customer retention (Garca-Fernández et al., 2018).

Based on the existing research gap, a mediating variable is needed that is able to answer the research gap. Continuous usage intention is closely related to loyalty. Commitment-trust theory explains how to develop long-term relationships between the parties involved. Users who trust an app are more likely to form long-term commitment. As a result, according to this idea, trust can be a variable that influences continual usage intention. Furthermore, while conversing online, trust is a critical component. In terms of protecting users' personal information, trust is described as a user's view that an IM application exhibits honesty, integrity, and competence (Mou et al., 2020). Trust is a technique to gauge the amount to which individuals expect positive results from specific behaviors or decisions, according to Wang et al. (2016b), and hence user trust in IM can inspire users to keep using the service. The largest user of the internet and its technology is Generation $\mathrm{Z}$. It is Generation $\mathrm{Z}$ who now dominates Indonesia and becomes the holder of the next country's development. The recorded population of Indonesia as of September 2020 was 270.20 million, or an increase of 32.56 million compared to 10 years ago. The domination of the population is in Generation $\mathrm{Z}$ as much as 27.94 percent, then followed by Millennials as much as 25.87 percent (Kompasiana, 2021). Gen $Z$ or millennials are those born between 1997 and 2012. While those born between 1981 and 1996, are part of millennials (Kumparan, 2019). This generation of Zillennial is called the most technologically savvy because it grows with the progress of the times. In this study, researchers are interested in seeing how millennials and millennials behave in their behavior using IM. Although there have been many previous studies that have raised this topic, researchers are interested in bringing up this topic because most of the previous research has researched on e-commerce, mobile banking, and social networking sites, but rarely has researched on instant messaging. In addition, there are still research gaps in the form of inconsistent results, and in previous studies using traditional theories rarely discussed the combination of subjective norms, perceived risk, perceived value, and trust, even though these factors are also important things that are of concern to many users. technology based services. In addition, this study also used two different sample groups, namely millennials and millennials.

\section{Literature Review}

\subsection{Perceived Risk}

When a user utilizes a product, perceived risk is defined as the degree to which the user perceives a functional or psychosocial risk (Akter \& Wamba, 2016). Users' faith in internet services has been eroded because of rising user risk perceptions as a 
result of regular cybercrime attacks (Akram et al., 2019). The more the user's trust, the lesser the user's perceived risk (Ha and Kim, 2020). Previous research conducted by Ali et al. (2021), Mou et al. (2020), Suki and Suki (2020), Rahmayanti and Rahyuda (2020) give the result that perceived risk has a negative and significant effect on trust. Furthermore, Sullivan and Kim (2018) discuss the dangers associated with trust because the lower the risk, the higher the likelihood of trust in e-commerce. Meanwhile, Nguyen and Huynh (2018) found that perceived risk had a negative but not statistically significant effect on trust. According to Milly et al. (2021) research, an increase in perceived risk reduces the likelihood of continuing to utilize mobile banking. These findings are backed up by studies by Park et al. (2019), Khan et al. (2020), and Obaid (2021), which found that perceived risk had a negative and substantial impact on continuing usage intention. Research Yi et al. (2020) stated that financial risk and privacy risk have a negative and significant influence on AirBnb adoption. Nuryasman and Warningsih (2021), on the other hand, found that perceived risk has no effect on the desire to use the product indefinitely. Thus, we defined the hypothesis as follows:

$\mathbf{H}_{1}$ : Perceived risk negatively affects trust on (a) Millennial or (b) Zillennial.

$\mathbf{H}_{2}$ : Perceived risk negatively affects continuous usage intention on (a) Millennial or (b) Zillennial.

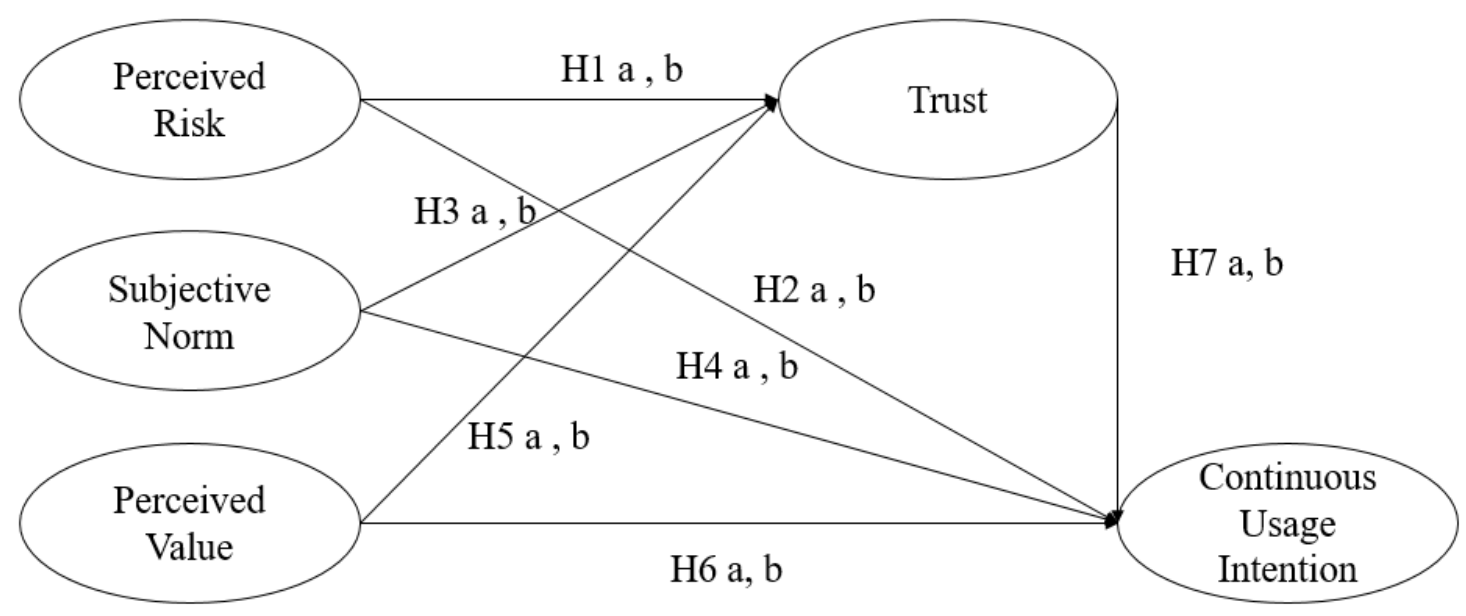

Fig. 1. Conceptual Framework

\subsection{Subjective Norm}

The perceived social pressure to perform or not perform a behavior is known as the subjective norm (Weng et al., 2017). There are specific standards, conventions, or attitudes regarding appropriate consumer behavior that apply to groups of people (Ghazali et al., 2017). The inclination of users to trust application developers in the context of mobile applications will most likely be based on extensive use of the app and the expectation of significant others that the app should be used. Subjective norms have an essential influence in the creation of online trust, according to previous studies (Hitosugi, 2011). Subjective norms have a favorable and significant effect on trust, according to Liu et al. (2020) and Kusumawardhani et al. (2019) research. Previous study has found that greater subjective norms are associated with higher intentions to use social media in a long-term manner (Lee et al., 2016; Gadhiya and Panchal Lee, 2021). Subjective norm has a favorable and significant effect on continuous usage intention, according to research conducted by Hossain et al. (2019), Mouakket (2018), Mkhize (2021), and Aji et al. (2020). Subjective norms, on the other hand, are less influential in driving user behavior in online communities due to voluntary involvement and relatively low switching costs (Rahmayanti and Rahyuda, 2020). Based on this, the hypotheses that can be developed in this study are:

\section{H3: Subjective norm positively affects trust on (a) Millennial or (b) Zillennial. \\ H4: Subjective norms positively affect continuous usage intention on (a) Millennial or (b) Zillennial.}

\subsection{Perceived Value}

Perceived value is related to appraising the product's overall utility, specifically in the give and take process. Non-monetary giving elements are assessed in terms of the time and effort spent utilizing the product or service (Jayashankar et al., 2018). According to research by Lai (2015) and Suki \& Suki (2020), perceived value has a favorable effect on trust. Perceived value had a favorable and significant impact on customer trust, according to Widiartini and Yasa (2017). Previous research has found that perceived value has a beneficial impact on future usage intentions (Hajli et al., 2015; Ahn et al., 2019). The findings of Huang and Shih's research (2019) emphasize the relevance of a conscious evaluation process in continuance intentions, with perceived value, which is included in the conscious component, having a positive and significant impact on intention to continue use. Thus, we defined the hypothesis as follows: 
Hs: Perceived value positively affects trust on (a) Millennial or (b) Zillennial.

H6: Perceived value positively affects continuous usage intention on (a) Millennial or (b) Zillennial.

\subsection{Trust}

User trust can be harmed by perceived risk. This is corroborated by Ali et al. (2021), Mou et al. (2020), Suki and Suki (2020), Rahmayanti and Rahyuda (2020) studies, which found that perceived risk has a negative and significant impact on trust. Trust influences the connection between subjective norms and technological adoption, according to Gong et al. (2019). Previous research has looked at how creating trust has a direct impact on e-wallet adoption intentions and sustainability (Rahmayanti \& Rahyuda, 2020). Trust in technology, according to Narahdita et al. (2020) and Ting (2020), can influence sustainability intentions to utilize that technology. Trust has a favorable and significant effect on intention to use, according to Concepcion and Orillano's research (2021). According to the theory of reasoned action (TRA), a user's belief in trust will influence behavioral intentions, which will influence actual conduct (Ajzen \& Fishbein, 1975; Ajzen, 1991). Obaid's research (2021) looks at how creating trust has a direct impact on mobile banking usage intentions and long-term adoption. Thus, we defined the hypothesis as follows:

H7: Trust positively affects continuous usage intention on (a) Millennial or (b) Zillennial.

H8: Trust mediates the relationship between perceived risk and continuous usage intention on (a) Millennial or (b) Zillennial.

H9: Trust mediates the relationship between subjective norm and continuous usage intention on (a) Millennial or (b) Zillennial

$\mathbf{H}_{10}$ : Trust mediates the relationship between perceived value and continuous usage intention on (a) Millennial or (b) Zillennial

\section{Methods}

\subsection{Sample Selection and Data Collection Procedure}

The sample in this study was an instant messaging (IM) user from Indonesia. An online survey was employed to collect the data by using google form. This method was used for more efficient data collection. By using this process, 320 completed questionnaires (160 from millennials and 160 from zillennial) gathered and used for hypothesis testing. The SmartPLS was used to analyze the structural model, including outer model (convergent validity with AVE, discriminant validity with FornellLarcker criterion, and composite reliability) and inner model (direct and indirect effect).

\subsection{Measurements}

The quantitative research setting for the empirical analysis was based on primary data obtained by a survey questionnaire. In this research, there were five sets of variables to be measured. The endogenous variable was continuous usage intention; the exogenous variables were perceived risk, subjective norm, and perceived value. The mediating variable was trust. These constructs were transformed into operational variables for true measuring. To measure each construct in the conceptual model, all variables were defined, and measured by survey questions that used a five-point Likert scale, ranging from 1 (strongly disagree) to 5 (strongly agree).

\section{Results and Discussion}

\subsection{The Measurement Models - Outer Model Testing}

The study of reflective models was conducted using the SmartPLS 3.2.8. For the measure of convergent validity from the analysis with average variance extracted (AVE), all values above 0.50 (factor loading) were statistically significant. The measure of discriminant validity was based on a correlation measurement between the latent variable where all values of the latent variable must be below the square root of AVE. The measure of discriminant validity was the Fornell-Larcker Criterion (measurement along a diagonal matrix) $>(A V E)^{2}$ (Fornell \& Larcker, 1981). In addition, reliability measurements were measured with composite reliability (CR), and Cronbach's alpha $(\alpha)$ values, with all reliability values greater than 0.70 (Hair et al., 2011).

The results of the statistical analysis of the measurement models were obtained from Table 1 . There were 35 observable variables in this research, each of which had a factor loading value between 0.736-0.895, with all variables having a loading value $>0.50$. The total AVE of all latent variables was between 0.643-0.725, with all variables having an AVE $>0.50$. The section of reliability consisted of composite reliability (CR), and an analysis of latent variables returned scores of between 0.881-0.929. The Dikstra-Henseler's rho $\left(\rho_{\mathrm{A}}\right)$ analysis of each variable was between $0.832-0.905$. Jöreskog's rho ( $\left.\rho_{\mathrm{C}}\right)$ analysis of latent variables was between 0.880-0.929. Cronbach's alpha $(\alpha)$ analysis of latent variables was between 0.821-0.904. In conclusion, $(\mathrm{CR}),\left(\rho_{\mathrm{A}}\right),\left(\rho_{\mathrm{C}}\right)$, and $(\alpha)$ values were all $>0.700$, indicating that all values were fit for the model analysis, as shown in Table 1. 
Table 1

Factor Loading, AVE, CR, $\rho_{\mathrm{A}}, \rho_{\mathrm{C}}$ and $\alpha$ Values

\begin{tabular}{|c|c|c|c|c|c|c|}
\hline \multirow{2}{*}{ Variables } & \multicolumn{3}{|c|}{ Millennial } & \multicolumn{3}{|c|}{ Zillennial } \\
\hline & Factor Loading & AVE & & Factor Loading & AVE & \\
\hline & & \multirow{5}{*}{0.750} & \multirow{5}{*}{0.923} & & \multirow[b]{5}{*}{0.753} & \multirow[b]{5}{*}{0.924} \\
\hline Using IM may can make my personal information leak (X2.1) & 0.800 & & & 0.811 & & \\
\hline It is not safe to use IM because of its privacy concerns (X2.2). & 0.895 & & & 0.892 & & \\
\hline There is a possibility of malfunctions in the IM system (X2.3). & 0.886 & & & 0.877 & & \\
\hline $\begin{array}{l}\text { There is a risk of hacking personal information when using IM } \\
\text { (X2.4). }\end{array}$ & 0.880 & & & 0.887 & & \\
\hline \multicolumn{2}{|l|}{ Subjective Norm (SN) } & \multirow{4}{*}{0.721} & \multirow{4}{*}{0.886} & & \multirow[b]{4}{*}{0.709} & \multirow[b]{4}{*}{0.880} \\
\hline Considering the opinion of the family in using IM (X1.1). & 0.889 & & & 0.879 & & \\
\hline Considering friends' opinions in using IM (X1.2). & 0.829 & & & 0.825 & & \\
\hline $\begin{array}{l}\text { Considering the opinions of other people who are considered im- } \\
\text { portant in using IM (X1.3). }\end{array}$ & 0.828 & & & 0.821 & & \\
\hline \multicolumn{2}{|l|}{ Perceived Value (PV) } & \multirow{4}{*}{0.639} & \multirow{4}{*}{0.842} & & \multirow{4}{*}{0.632} & \multirow{4}{*}{0.838} \\
\hline I feel the IM provided me with a good value (X3.1) & 0.804 & & & 0.803 & & \\
\hline The IM is valuable to me (X3.2) & 0.767 & & & 0.771 & & \\
\hline I feel I am getting good service from the IM (X3.3) & 0.827 & & & 0.810 & & \\
\hline \multicolumn{2}{|l|}{ Trust (TR) } & \multirow{4}{*}{0.835} & \multirow{4}{*}{0.938} & & \multirow{4}{*}{0.826} & \multirow{4}{*}{0.934} \\
\hline Believe IM can protect user privacy (Y1.1) & 0.929 & & & 0.929 & & \\
\hline Trust IM does not use personal data for anything else (Y1.2). & 0.925 & & & 0.917 & & \\
\hline Trust in IM security (Y1.3). & 0.887 & & & 0.880 & & \\
\hline \multicolumn{5}{|l|}{ Continuous Usage Intention (CUI) } & \multirow{4}{*}{0.785} & \multirow{4}{*}{0.916} \\
\hline Intend to continue using $\mathrm{IM}(\mathrm{Y} 2.1)$ & 0.877 & \multirow{3}{*}{0.802} & \multirow{3}{*}{0.924} & 0.856 & & \\
\hline Intend to use IM in the future (Y2.3). & 0.897 & & & 0.892 & & \\
\hline Intend to recommend the use of IM to others (Y2.3) & 0.912 & & & 0.909 & & \\
\hline
\end{tabular}

The results of the study were analyzed for discriminant validity in Table 2; the Fornell-Larcker criterion was used for all six latent variables by structure. The diagonal AVE matrix and the correlation of the latent variable for each passive variable, whose value $(\mathrm{AVE})^{2}$ should be greater than the correlation between the passive variables. The values of the latent variables in Table 2, along the diagonal line, ranged from 0.795-0.914. The results of all of them were considered greater than the correlation between the latent variables. From all of these results, consideration of the outer model indicated that it had validity and reliability leading to an interpretable structural model.

Table 2

Discriminant Validity Test Using Fornell-Larcker Criterion

\begin{tabular}{|c|c|c|c|c|c|c|c|c|c|c|}
\hline & \multicolumn{5}{|c|}{ Millennial } & \multicolumn{5}{|c|}{ Zillennial } \\
\hline & CUI & PR & PV & $\mathrm{SN}$ & TR & CUI & PR & PV & $\mathrm{SN}$ & TR \\
\hline CUI & 0.896 & & & & & 0.886 & & & & \\
\hline PR & -0.610 & 0.866 & & & & -0.279 & 0.868 & & & \\
\hline PV & 0.659 & -0.478 & 0.800 & & & 0.661 & -0.225 & 0.795 & & \\
\hline $\mathrm{SN}$ & 0.664 & -0.470 & 0.752 & 0.849 & & 0.664 & -0.124 & 0.761 & 0.842 & \\
\hline TR & 0.706 & -0.640 & 0.637 & 0.627 & 0.914 & 0.726 & -0.405 & 0.654 & 0.631 & 0.909 \\
\hline
\end{tabular}

\subsection{The Structural Model - Inner Model Testing}

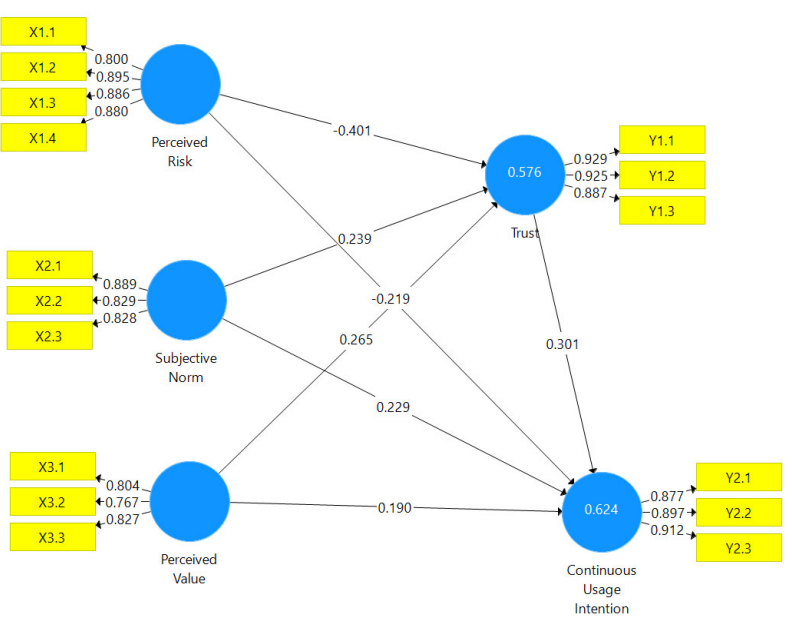

(a)

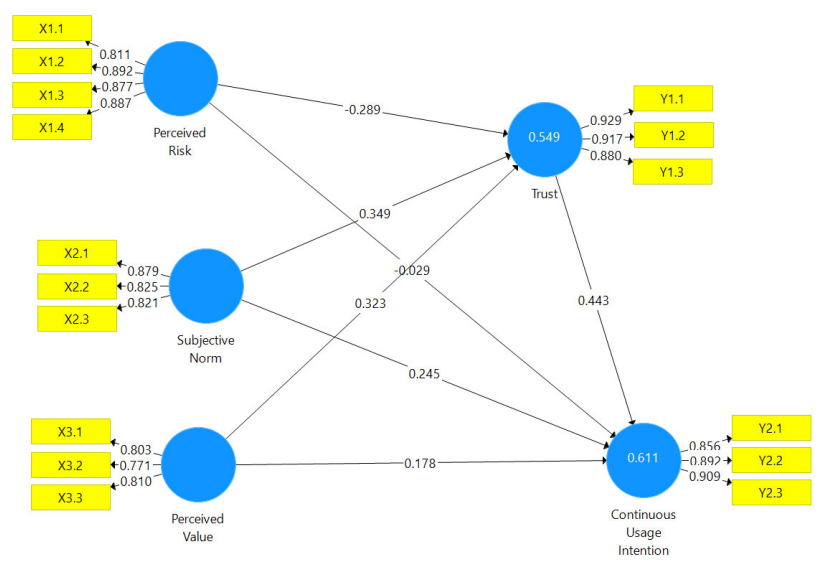

(b)

Fig. 2. The Structural Model (a) on Millennial and (b) on Zillennial 
Fig. 2 the hypothesis testing of the structure model found that out of 20 hypotheses tested for the structural model, a total of 19 hypotheses were accepted, and a total of 1 were rejected. However, the primary evaluation criteria for the structural model were the $\mathrm{R}^{2}$ measures, with values of between $0.431-0.634$, which were at a moderate level. Therefore, all hypothesis testing results can be considered in more detail in Table 3.

Table 3

Hypothesis Testing Results

\begin{tabular}{|c|c|c|c|c|c|}
\hline Hypothesis & Path & S.E. & t-value & p-value & Results \\
\hline H1a: PR $\rightarrow$ TR & -0.401 & 0.065 & 6.186 & $0.000^{* * *}$ & Accepted \\
\hline H1b: PR $\rightarrow$ TR & 0.289 & 0.052 & 5.556 & $0.000^{* * *}$ & Accepted \\
\hline H2a: PR $\rightarrow$ CUI & -0.219 & 0.063 & 3.505 & $0.000^{* * *}$ & Accepted \\
\hline $\mathrm{H} 2 \mathrm{~b}: \mathrm{PR} \rightarrow \mathrm{CUI}$ & -0.029 & 0.047 & 0.068 & 0.544 & Rejected \\
\hline H3a: SN $\rightarrow$ TR & 0.239 & 0.080 & 3.005 & $0.003^{* *}$ & Accepted \\
\hline $\mathrm{H} 3 \mathrm{~b}: \mathrm{SN} \rightarrow \mathrm{TR}$ & 0.349 & 0.081 & 4.290 & $0.000^{* * * *}$ & Accepted \\
\hline H4a: SN $\rightarrow$ CUI & 0.229 & 0.087 & 2.628 & $0.009^{* *}$ & Accepted \\
\hline $\mathrm{H} 4 \mathrm{~b}: \mathrm{SN} \rightarrow \mathrm{CUI}$ & 0.245 & 0.087 & 2.818 & $0.005^{* *}$ & Accepted \\
\hline H5a: PV $\rightarrow$ TR & 0.265 & 0.083 & 3.207 & $0.001^{* *}$ & Accepted \\
\hline H5b: PV $\rightarrow$ TR & 0.323 & 0.085 & 3.806 & $0.000^{* * * *}$ & Accepted \\
\hline H6a: PV $\rightarrow$ CUI & 0.190 & 0.076 & 2.497 & $0.013^{*}$ & Accepted \\
\hline H6b: PV $\rightarrow$ CUI & 0.187 & 0.079 & 2.267 & $0.024^{*}$ & Accepted \\
\hline H7a: TR $\rightarrow$ CUI & 0.301 & 0.079 & 3.793 & $0.000^{* * *}$ & Accepted \\
\hline H7b: TR $\rightarrow$ CUI & 0.443 & 0.085 & 5.197 & $0.000^{* * * *}$ & Accepted \\
\hline H8a: PR $\rightarrow$ TR $\rightarrow$ CUI & -0.121 & 0.038 & 3.204 & $0.001^{* *}$ & Accepted \\
\hline H8b: PR $\rightarrow$ TR $\rightarrow$ CUI & -0.128 & 0.036 & 3.567 & $0.000^{* * * *}$ & Accepted \\
\hline H9a: SN $\rightarrow$ TR $\rightarrow$ CUI & 0.072 & 0.030 & 2.419 & $0.016^{*}$ & Accepted \\
\hline $\mathrm{H} 9 \mathrm{~b}: \mathrm{SN} \rightarrow \mathrm{TR} \rightarrow \mathrm{CUI}$ & 0.155 & 0.047 & 3.271 & $0.001^{* *}$ & Accepted \\
\hline H10a: PV $\rightarrow$ TR $\rightarrow$ CUI & 0.089 & 0.032 & 2.481 & $0.013^{*}$ & Accepted \\
\hline H10b: PV $\rightarrow$ TR $\rightarrow$ CUI & 0.143 & 0.046 & 3.139 & $0.002^{* *}$ & Accepted \\
\hline
\end{tabular}

Note: * Significant at the 0.05 level. ** Significant at the 0.01 level. *** Significant at the 0.001 level.

\subsection{Discussion}

First, this research assesses continuous usage intention among IM users based on their generation (millennials and Zillennial). To predict continuous usage intention, this research integrates perceived risk, subjective norm, perceived value, and trust as determinants. The results of the analysis disclose the model is fit. From fourteen hypotheses of direct effect formulated, 13 hypotheses accepted and 1 hypotheses rejected. Thus, the integration of perceived risk, subjective norm, perceived value, and trust increase the prediction power of continuous usage intention among millennials and zillennial, except the effect of perceived risk on zillennial continuous usage intention of IM is negative and not significant (H2b rejected). This result implies that perceived risk, subjective norm, perceived value, and trust of millennials reinforce their continuous usage intention toward IM. The finding for sample from millennials corroborates with past studies, which reveal that perceived risk is key factor in influencing continuous usage intention of millennials (Ali et al., 2021; Mou et al., 2020, Suki dan Suki, 2020; Rahmayanti dan Rahyuda, 2020). The other finding for sample from millennials corroborates with past studies, which reveal that subjective norm and perceived value is key factor in influencing continuous usage intention of millennials and zillennial (Hossain et al., 2019; Mouakket, 2018; Mkhize, 2021; Aji et al., 2020; Hajli et al., 2015; Ahn dan Lee, 2019; Rahmayanti dan Rahyuda, 2020; Narahdita et al., 2020; Ting, 2020; Venkatesh et al., 2003).

Second, in terms of perceived risk, this research notes a conflicting result between samples from millennials and zillennial. While perceived risk is negative and significant in influencing continuous usage intention on millennial, this factor is not significant for zillennial. In zillennial, perceived risk is negative and not significant in influencing continuous usage intention. The finding for sample from zillennial corroborates with past studies (Nuryasman \& Warningsih, 2021).

Third, this research also tested the indirect effect and all indirect effect relationships are significant. Based on indirect effects, test results show that H8a, H8b, H9a, H9b, H10a, H10b were significant. Because direct effect test results from H1a, H1b, $\mathrm{H} 2 \mathrm{a}, \mathrm{H} 3 \mathrm{a}-\mathrm{H} 7(\mathrm{a}, \mathrm{b})$ were significant, its conditions represent partial mediation. However, because H2b is not significant, we should calculate the variance accounted for (VAF) to determine the extent to which the mediation process explains the dependent variable's variance. The criteria for assessing the mediating effect can be based on the VAF value. If the VAF value is $>80 \%$, it shows the mediation variable as full mediation); if the VAF value is between $20 \%-80 \%$, then it shows the mediating variable as partial mediation; and if the value of $\mathrm{VAF}<20 \%$, it can be concluded that the mediating variable does not act as a mediator. Based on VAF calculation results, the VAF value of $\mathrm{H} 8 \mathrm{~b}$ is $0,8152(81,52 \%)$. This VAF value is $>80 \%$. That is, the variable of trust is classified as full mediation in mediating the effect of perceived risk on continuous usage intention in zillennial. This means that the perceived risk will not affect the continuous usage intention of zillennial if they have trust in the system, if zillennial feels that the risk of using IM is high then they do not necessarily stop using IM and vice versa. However, if zillennial feel the risk of using IM is high and they have low trust then zillennial will not continue to use IM. This is because the zillennial generation who have been accustomed to living with the internet since childhood causes 
them to consider the perceived risk to have little impact on their continuous use of technology, except when they already have low trust in the technology, this will reduce their continuous usage of technology.

\section{Conclusion}

This study aimed to explore the relationship between perceived risk, subjective norm, and perceived value on continuous usage intention via trust as a mediating factor on two different generations. This study uses data from 320 IM users (160 from millennials and 160 from Zillennial) in Indonesia. The results of the study found that continuous usage intention received negative direct impact from perceived risk, positive direct effect from subjective norm, perceived value, and trust on Millennial. In addition, continuous usage intention received negative and not significant direct impact from perceived risk, positive direct effect from subjective norm, perceived value, and trust on Zillennial. The results of the study also received significant indirect impact from perceived risk, subjective norm, and perceived value through trust. Moreover, trust acts as an intermediary for the transmission of perceived risk, subjective norm, and perceived value to continuous usage intention. In conclusion, the IM management should develop a strategy in terms of perceived risk, subjective norm, and perceived value, including the development of mediating variables on trust to gain for continuous usage intention. This research was conducted only to investigate the millennials and zilenials IM users in Indonesia, which has a unique identity among population groups. The future research possibilities included the study of other types of population groups to make comparisons and analysis of the differences in the results. Finally, the author of this study hopes that empirical evidence for the role of trust on continuous usage intention of context instant messenger in Indonesia will stimulate in depth research on this subject in the future. This is also an important aspect of marketing management studies.

\section{References}

Ahn, J., Lee, C. K., Back, K. J., \& Schmitt, A. (2019). Brand experiential value for creating integrated resort customers' cocreation behavior. International journal of hospitality management, 81, 104-112.

Aji, H. M., Albari, A., Muthohar, M., Sumadi, S., Sigit, M., Muslichah, I., \& Hidayat, A. (2020). Investigating the determinants of online infaq intention during the COVID-19 pandemic: an insight from Indonesia. Journal of Islamic Accounting and Business Research.

Ajzen, I. (1991). The theory of planned behavior. Organizational behavior and human decision processes, 50(2), 179-211.

Ajzen, I., \& Fishbein, M. (1975). A Bayesian analysis of attribution processes. Psychological bulletin, 82(2), 261.

Akram, M. S., Malik, A., Shareef, M. A., \& Goraya, M. A. S. (2019). Exploring the interrelationships between technological predictors and behavioral mediators in online tax filing: The moderating role of perceived risk. Government Information Quarterly, 36(2), 237-251.

Akter, S., \& Wamba, S. F. (2016). Big data analytics in E-commerce: a systematic review and agenda for future research. Electronic Markets, 26(2), 173-194.

Ali, M., Raza, S. A., Khamis, B., Puah, C. H., \& Amin, H. (2021). How perceived risk, benefit and trust determine user Fintech adoption: a new dimension for Islamic finance. foresight.

Bussiness Insider. (2019). WhatsApp Hacked and Attackers Installed NSO Group Spyware. http://businessinsider.com/

Concepcion, M. M., \& Orillano, M. P. (2021). The effect of perceived online risk and trust affecting theconsumers' behavioral intention in usingelectronic commerce. The Journal of Social Sciences Studies and Research, 1(01), 1-11.

Davis, F. D. (1989). Perceived usefulness, perceived ease of use, and user acceptance of information technology. MIS quarterly, 319-340.

Deng, Z., \& Liu, S. (2017). Understanding consumer health information-seeking behavior from the perspective of the risk perception attitude framework and social support in mobile social media websites. International journal of medical informatics, 105, 98-109.

Gadhiya, P., \& Panchal, N. (2021). Young Women's Continuance Intentions to use Communication and Social Media Apps. Indian Journal of Marketing, 51(3), 41-55.

García-Fernández, J., Gálvez-Ruíz, P., Fernández-Gavira, J., Vélez-Colón, L., Pitts, B., \& Bernal-García, A. (2018). The effects of service convenience and perceived quality on perceived value, satisfaction and loyalty in low-cost fitness centers. Sport Management Review, 21(3), 250-262.

Ghazali, E., Soon, P. C., Mutum, D. S., \& Nguyen, B. (2017). Health and cosmetics: Investigating consumers' values for buying organic personal care products. Journal of Retailing and Consumer Services, 39, 154-163.

Gong, Z., Han, Z., Li, X., Yu, C., \& Reinhardt, J. D. (2019). Factors influencing the adoption of online health consultation services: the role of subjective norm, trust, perceived benefit, and offline habit. Frontiers in public health, 7, 286.

Ha, T., Kim, S., Seo, D., \& Lee, S. (2020). Effects of explanation types and perceived risk on trust in autonomous vehicles. Transportation research part F: traffic psychology and behaviour, 73, 271-280.

Hair, J. F., Ringle, C. M., \& Sarstedt, M. (2011). PLS-SEM: Indeed a silver bullet. Journal of Marketing theory and Practice, $19(2), 139-152$

Hajli, N., Shanmugam, M., Powell, P., \& Love, P. E. (2015). A study on the continuance participation in on-line communities with social commerce perspective. Technological Forecasting and Social Change, 96, 232-241. 
Nuryasman, M. N., \& Warningsih, S. (2021). Determining Factors of Digital Wallet Usage. Jurnal Manajemen, 25(2), 271289.

Hitosugi, K. (2011). Trust on the web: the power of subjective norm across cultures. University of Hawaii at Manoa.[Online]. Available at URL: http://claireh. weebly. com/uploads/5/2/9/9/5299882/hitosugi_sninonlinetrust_crosscultureconf_dec2011. pdf [Accessed October 14th, 2014].

Ho, S. M., Ocasio-Velázquez, M., \& Booth, C. (2017). Trust or consequences? Causal effects of perceived risk and subjective norms on cloud technology adoption. Computers \& Security, 70, 581-595.

Hossain, M. A. (2019). Effects of uses and gratifications on social media use: The Facebook case with multiple mediator analysis. PSU Research Review.

Huang, H. Y., \& Shih, S. P. (2019). REMAINING ON CURRENT SOCIAL NETWORK SITES: AN UNCONSCIOUS AND CONSCIOUS PERSPECTIVE. Journal of Electronic Commerce Research, 20(2).

Jayashankar, P., Nilakanta, S., Johnston, W. J., Gill, P., \& Burres, R. (2018). IoT adoption in agriculture: the role of trust, perceived value and risk. Journal of Business \& Industrial Marketing.

Khan, S. U., Liu, X., Khan, I. U., Liu, C., \& Rasheed, M. I. (2020). Assessing the investors' acceptance of electronic stock trading in a developing country: the Mediating role of perceived risk dimensions. Information Resources Management Journal (IRMJ), 33(1), 59-82.

Kompasiana. (2021). Indonesia Didominasi Generasi Milenial dan Generasi Z, Apa Plus Minusnya?. https:/www.kompas.com/tren/read/2021/01/23/163200065/indonesia-didominasi-generasi-milenial-dan-generasi-z-apaplus-minusnya-?page $=$ all

Kumar, V., \& Reinartz, W. (2016). Creating enduring customer value. Journal of Marketing, 80(6), 36-68.

Kumparan. (2019). Jangan Salah, Ini Bedanya Milenial dengan Generasi Z. https://kumparan.com/millennial/jangan-salahini-bedanya-milenial-dengan-generasi-z-1qfqa4Ibm7I

Kurdi, B. A., Alshurideh, M., Nuseir, M., Aburayya, A., \& Salloum, S. A. (2021, March). The effects of subjective norm on the intention to use social media networks: an exploratory study using PLS-SEM and machine learning approach. In International Conference on Advanced Machine Learning Technologies and Applications (pp. 581-592). Springer, Cham.

Kusumawardhani, A., Batu, K. L., \& Aqmala, D. (2019). How Green should Trust, Norm and Attitude be Colored? An Empirical Research in Asian Market Consumers. Calitatea, 20(168), 118-126.

Lai, Y. H. (2015). Enhance online purchase intentions: the role of perceived value, trust and commitment. Journal of Tourism and Hospitality Management, 3(2), 89-99.

Lee, J. W. C., \& Tanusia, A. (2016, August). Energy conservation behavioural intention: Attitudes, subjective norm and selfefficacy. In IOP conference series: Earth and environmental science (Vol. 40, No. 1, p. 012087). IOP Publishing.

Liu, R. D., Wang, J., Gu, D., Ding, Y., Oei, T. P., Hong, W., ... \& Li, Y. M. (2019). The effect of parental phubbing on teenager's mobile phone dependency behaviors: The mediation role of subjective norm and dependency intention. Psychology research and behavior management, 12, 1059.

Milly, N., Xun, S., Meena, M. E., \& Cobbinah, B. B. (2021). Measuring Mobile Banking Adoption in Uganda Using the Technology Acceptance Model (TAM2) and Perceived Risk. Open Journal of Business and Management, 9(01), 397.

Mkhize, N. H. (2021). Influencing the adoption of microgeneration technologies using the theory of planned behaviour. South African Journal of Business Management, 52(1), 9.

Mou, J., Cui, Y., \& Kurcz, K. (2020). Trust, risk and alternative website quality in B-buyer acceptance of cross-border Ecommerce. Journal of Global Information Management (JGIM), 28(1), 167-188.

Mouakket, S. (2018). The role of personality traits in motivating users' continuance intention towards Facebook: Gender differences. The Journal of High Technology Management Research, 29(1), 124-140.

Nabavi, A., Taghavi-Fard, M. T., Hanafizadeh, P., \& Taghva, M. R. (2016). Information technology continuance intention: A systematic literature review. International Journal of E-Business Research (IJEBR), 12(1), 58-95

Narahdita, A. P., Aisjah, S., \& Kusniyah, N. (2020). Trust and Perceived Benefit as Antecedents of Reuse Intention in Mobile Payment Services. Jurnal Aplikasi Manajemen, 18(4), 682-691.

Nguyen, T. D., \& Huynh, P. A. (2018, January). The roles of perceived risk and trust on e-payment adoption. In International econometric conference of Vietnam (pp. 926-940). Springer, Cham.

Obaid, T. (2021). Predicting Mobile Banking Adoption: An Integration of TAM and TPB With Trust and Perceived Risk. Available at SSRN 3761669.

Park, M., Oh, H., \& Lee, K. (2019). Security risk measurement for information leakage in IoT-based smart homes from a situational awareness perspective. Sensors, 19(9), 2148.

Rahmayanti, P.L.D dan Rahyuda, I.K. (2020). The Role Of Trust In Mediating The Effect Of Perceived Risk And Subjective Norm On Continuous Usage Intention On Gopay Users In Denpasar. RJOAS: Russian Journal of Agricultural and SocioEconomic Sciences. 12(108), pp 69-80

Rogers, R. D., \& Monsell, S. (1995). Costs of a predictible switch between simple cognitive tasks. Journal of experimental psychology: General, 124(2), 207.

Salleh \& K., Laxman (2015). Examining the effect of external factors and context dependent beliefs of teachers in the use of ICT in teaching: Using an elaborated theory of planned behavior. Journal of Educational Technology Systems, 43(3), 289319.

Shaikh, A. A., \& Karjaluoto, H. (2016). On some misconceptions concerning digital banking and alternative delivery channels. International Journal of E-Business Research (IJEBR), 12(3), 1-16. 
Statistica. (2021). Most popular global mobile messenger apps as of April 2021, based on number of monthly active users. https://www.statista.com/statistics/258749/most-popular-global-mobile-messenger-apps/

Suki, N.M, \& Mohd Suki, N. (2020). Acquiring travel-related information from mobile social networking services: What factors predict social networking services users' perceived value and trust in Malaysia?. Journal of Marketing Communications, 26(7), 742-760.

Sullivan, Y. W., \& Kim, D. J. (2018). Assessing the effects of consumers' product evaluations and trust on repurchase intention in e-commerce environments. International Journal of Information Management, 39, 199-219.

TING, S. L. J. (2020). Deconstructing the wallet: effects of social norms, trust and perceived risk on the adoption of mobile wallets.

Venkatesh, V., Morris, M. G., Davis, G. B., \& Davis, F. D. (2003). User acceptance of information technology: Toward a unified view. MIS Quarterly, 27(3), 425-478.

Wang, W. Y., Pauleen, D. J., \& Zhang, T. (2016a). How social media applications affect B2B communication and improve business performance in SMEs. Industrial Marketing Management, 54, 4-14.

Wang, W. T., Wang, Y. S., \& Liu, E. R. (2016b). The stickiness intention of group-buying websites: The integration of the commitment-trust theory and e-commerce success model. Information \& Management, 53(5), 625-642.

Weng, G. S., Zailani, S., Iranmanesh, M., \& Hyun, S. S. (2017). Mobile taxi booking application service's continuance usage intention by users. Transportation Research Part D: Transport and Environment, 57, 207-216.

Widiartini, P. R., \& Yasa, N. N. K. (2017). Peran kepercayaan dalam memediasi hubungan persepsi nilai dengan niat menggunakan e-money. Matrik: Jurnal Manajemen, Strategi Bisnis dan Kewirausahaan, 11(1), 11-25.

Yi, J., Yuan, G., \& Yoo, C. (2020). The effect of the perceived risk on the adoption of the sharing economy in the tourism industry: The case of Airbnb. Information Processing \& Management, 57(1), 102108.

Zeithaml, V. A., Berry, L. L., \& Parasuraman, A. (1988). Communication and control processes in the delivery of service quality. Journal of marketing, 52(2), 35-48. 
(C) 2022 by the authors; licensee Growing Science, Canada. This is an open access article distributed under the terms and conditions of the Creative Commons Attribution (CC-BY) license (http://creativecommons.org/licenses/by/4.0/). 